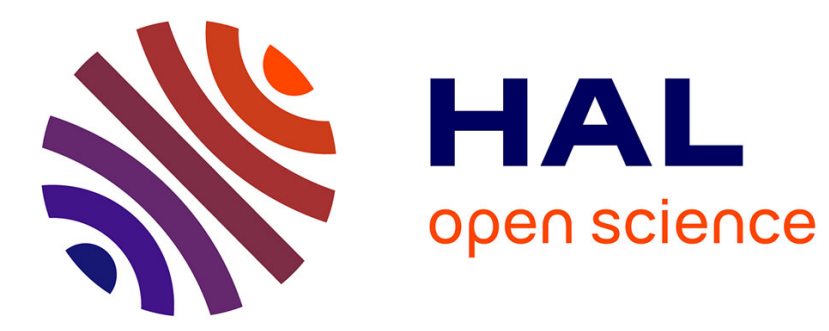

\title{
Occurrence of ochratoxin A in Algerian wheat and its milling derivatives
}

Saliha Zebiri, Salim Mokrane, Carol Verheecke, Élodie Choque, Hocine Reghioui, Nasserdine Sabaou, Florence Mathieu, Amar Riba

\section{To cite this version:}

Saliha Zebiri, Salim Mokrane, Carol Verheecke, Élodie Choque, Hocine Reghioui, et al.. Occurrence of ochratoxin A in Algerian wheat and its milling derivatives. Toxin Reviews, 2018, 37, pp.1-6. 10.1080/15569543.2018.1438472 . hal-01981534

\section{HAL Id: hal-01981534 \\ https://hal.science/hal-01981534}

Submitted on 15 Jan 2019

HAL is a multi-disciplinary open access archive for the deposit and dissemination of scientific research documents, whether they are published or not. The documents may come from teaching and research institutions in France or abroad, or from public or private research centers.
L'archive ouverte pluridisciplinaire HAL, est destinée au dépôt et à la diffusion de documents scientifiques de niveau recherche, publiés ou non, émanant des établissements d'enseignement et de recherche français ou étrangers, des laboratoires publics ou privés. 


\section{Open Archive Toulouse Archive Ouverte (OATAO)}

OATAO is an open access repository that collects the work of Toulouse researchers and makes it freely available over the web where possible

This is an author's version published in: http://oatao.univ-toulouse.fr/21141

Official URL: https://doi.org/10.1080/15569543.2018.1438472

\section{To cite this version:}

Zebiri, Saliha and Mokrane, Salim and Verheecke, Carol $\stackrel{5}{\leftrightarrows}$ and Choque, Élodie Reghioui, Hocine and Sabaou, Nasserdine and Mathieu, Florence Occurrence of ochratoxin A in Algerian wheat and its milling derivatives. (2018) Toxin Reviews, 37. 1-6. ISSN 1556-9543

Any correspondence concerning this service should be sent to the repository administrator: tech-oatao@listes-diff.inp-toulouse.fr 


\title{
Occurrence of ochratoxin A in Algerian wheat and its milling derivatives
}

\author{
Saliha Zebiri ${ }^{a}$, Salim Mokrane ${ }^{a}$, Carol Verheecke-Vaessen ${ }^{b, c}$, Elodie Choque ${ }^{b}$, Hocine Reghioui ${ }^{a}$, \\ Nasserdine Sabaou ${ }^{a}$, Florence Mathieu ${ }^{b}$ and Amar Riba ${ }^{a, d}$ (iD \\ aLaboratoire de Biologie des Systèmes Microbiens, Ecole Normale Supérieure de Kouba, Chikh Mohamed El Bachir El Ibrahimi, Alger, \\ Algeria; 'Université de Toulouse, Laboratoire de Génie Chimique UMR 5503 (CNRS/INPT/UPS), INP de Toulouse/ENSAT, Castanet- \\ Tolosan Cedex, France; 'Applied Mycology Group, AgriFood Theme, Cranfield University, Cranfield, Bedford, UK; ${ }^{\mathrm{d} D e ́ p a r t e m e n t ~ d e ~}$ \\ Biologie, Faculté des Sciences, Université M'Hamed Bougara, Boumerdes, Algeria
}

\begin{abstract}
To determine the concentrations of ochratoxin A in wheat, and its derivatives, 81 samples, including durum wheat $(n=27)$, common wheat $(n=12)$, semolina $(n=29)$ and flour $(n=13)$ were collected from regions of Algeria. The results showed that 62 of the 81 samples (76.54\%), were contaminated with quantities of ochratoxin A ranging from 0.84 to $34.75 \mu \mathrm{g} / \mathrm{kg}$. The results showed that $69.23 \%$ of wheat grains were contaminated with ochratoxin A $(0.21-27.31 \mu \mathrm{g} / \mathrm{kg})$. Ochratoxin A were detected both in semolina and flour manufacturing process $(0.16-34.75 \mu \mathrm{g} / \mathrm{kg})$. Ochratoxin A level seem to be a serious public health problem in Algeria.
\end{abstract}

KEYWORDS Mycotoxins; wheat products; flour; semolina; HPLC-FD; Algeria

\section{Introduction}

Mycotoxins are secondary metabolites showing toxicity via a natural route of exposure (ingestion or inhalation routes). They have harmful effects on humans, animals, and crops, resulting in illnesses and economic losses. Wheat and its products are susceptible to fungal attack, either in the field or during storage. The stored wheat grains are susceptible to contamination by various molds even under general storage conditions (Tabuc et al. 2009), which can cause serious deterioration of the grains. These fungi may produce mycotoxins. Ochratoxin A (OTA) produced by members of the genera Penicillium (e.g. Penicillium verrucosum) and Aspergillus (e.g. Aspergillus westerdijkiae) is frequently found in agricultural commodities and foods made from wheat (Duarte et al. 2010). Presence of mycotoxins is a serious worldwide problem in wheat and other cereals. Feedstuffs of plant origin like those made of wheat, oats, barley, etc., may contain from 1 to $100 \mu \mathrm{g} / \mathrm{kg}$ of OTA (Malir et al. 2016). OTA is a nephrotoxic mycotoxin with carcinogenic, immunosuppressive, and teratogenic properties (IARC 1999; Murphy et al. 2006). Some studies have found the implication of OTA in certain epidemic nephropathies in animals and humans (Pfohl-Leszkowicz et al. 2002; Bennett and Klich 2003; Castegnaro et al. 2006). Due to the health hazards to humans and animals, the maximum permitted levels for OTA were set to $5 \mu \mathrm{g} / \mathrm{kg}$ for whole grains and $3 \mu \mathrm{g} / \mathrm{kg}$ for processed products (European Commission 2006). OTA has been reported in wheat in North African country (Hajjaji et al. 2006; Riba et al. 2008; Zaied et al. 2009; Zinedine et al. 2009; Jedidi et al. 2016) and in cereal-based products (KuiperGoodman 1996; Wolff 2000; Czerwiecki et al. 2002a,2002b; Lombaert et al. 2003; Kumar et al. 2012; Vidal et al. 2013). Consequently, changes in mycotoxin distribution and concentration during the milling process become a worldwide topic of interest. The fate of OTA during cereal processing, such as sorting, cleaning, and milling was studied by many authors worldwide (Binder et al. 2007; Bullerman and Bianchini 2007; Kabak 2009; Rodrigues and Naehrer 2012). OTA can be very stable to food processing, thus it can be found in final products (Osborne et al. 1996; Araguas et al. 2005).

In 2016, cereal production in Algeria was estimated at $\sim 3.3$ million tons (FAO, 2016); where, Durum wheat is the main cereal produced. Therefore, and to fulfill its requirements, the Algerian government import an average of 6 million tons of wheat per year. Wheat is considered as a basic staple food for Algerian population. Thus, the determination of its content of OTA must be taken with more thoughtfulness. Till now, Algeria has not established a maximum level for OTA

CONTACT Amar Riba riba_amar@yahoo.fr @ Laboratoire de Biologie des Systèmes Microbiens (LBSM), Ecole Normale Supérieure de Kouba, BP 92, 16 050, Kouba, Alger, Algeria 
in food and foodstuff and little is known about levels of OTA in wheat and their products (Riba et al. 2008). The aim of this study is to evaluate the occurrence of OTA in durum and common wheat, and in some of its derived products issued from different stages of processing.

\section{Material and methods}

\section{Samples collection}

The concentration of OTA was determined in 81 samples including 39 samples of wheat: 27 of durum wheat (DW) and 12 of common wheat (CW). Samples were collected from four localities in Algeria: (i) Médéa and Mitidja, in the north-central region, (ii) Sétif and Tiaret located respectively in north-eastern and northwestern Highlands. The Samples were taken after 4 months of storage in silos and warehouses from 2012 and 2013 harvest. Altogether, a sub-sample of $300-400 \mathrm{~g}$ was taken through the "trench-type" silo in a transect at three levels (low, middle and high) and combined to give a sample of $\sim 1 \mathrm{~kg}$. Furthermore, 42 samples of wheat-derived products (29 from DW and 13 from (W) were collected during 2014 from M'sila mills (semolina and flour manufactures). Samples were collected by experienced personnel during the mills' routine intake sampling procedure. For each Mill, samples of $1 \mathrm{~kg}$ were taken at steps of production chain. Samples were from unclean and cleaned wheat, milling stages and final products (flour, semolina, bran and middlings). For each sample, $1 \mathrm{~kg}$ was stored in sealed sterile paper bags at $-20^{\circ} \mathrm{C}$ until use.

\section{OTA analysis in wheat and wheat-derived products}

\section{OTA extraction}

OTA from wheat samples and derived products was extracted according to the method described by the suppliers of Ota clean ${ }^{\text {TM }}$ SMART immunoaffinity columns (LC Tech, Obertaufkirchen, Germany). Samples were ground into fine powder and subsamples of $20 \mathrm{~g}$ were taken and mixed with $100 \mathrm{ml}$ of methanol: water (80:20, v/v) and grinded for $3 \mathrm{~min}$ at a high speed in a blender. The extract was then filtered through a Whatman $\mathrm{N}^{\circ} 1$ filter paper. Three milliliter of the filtrate was diluted with $12 \mathrm{ml}$ of phosphate-buffered saline (PBS) solution, then $10 \mu \mathrm{L}$ of the mix were drained through an OTA-specific immunoaffinity column (IAC) (LCTech GmbH). The columns were then washed with $2 \mathrm{ml}$ of distilled water, and the OTA was eluted with $0.4 \mathrm{ml}$ of methanol.
OTA quantification by high-performance liquid chromatography

OTA was detected and quantified by the Thermo Scientific $^{\mathrm{TM}}$ Dionex $^{\mathrm{TM}}$ UltiMate $^{\mathrm{TM}} 3000$ (Dionex, France) reversed-phase high-performance liquid chromatography (HPLC) equipped with a fluorescence detector (HPLC-FLD). The excitation $\left(\lambda_{e x}\right)$ and emission $\left(\lambda_{e m}\right)$ wavelengths were set at 332 and $466 \mathrm{~nm}$, respectively. An aliquot of $100 \mu \mathrm{L}$ from each sample was injected using an auto-injector. The analytical column was Prontosil $150-5-\mathrm{C} 18(150 \times 4.6 \mathrm{~mm})$ preceded by a $10 \times 4.3 \mathrm{~mm} \mathrm{C18}$ guard column. The column temperature was $30^{\circ} \mathrm{C}$. The mobile phase used consisted of acetonitrile:water:acetic acid (50:49.8:0.2) at a flow rate of $0.8 \mathrm{ml} / \mathrm{min}$. The injection volume was $100 \mu \mathrm{L}$. Quantification was carried out by measuring the peaks areas according to a pre-established standard curve.

\section{Method validation for determination of OTA}

The analytical method was validated by the evaluation of linearity, limits of detection (LOD) and quantification (LOQ), precision and trueness based on recovery studies for three matrix, wheat grain, fine semolina and flour. The linearity of the method was assessed by analyzing OTA concentrations in the range $1-50 \mu \mathrm{g} / \mathrm{kg}$ in triplicate. The data for peak area were treated by linear regression analysis and linearity was expressed as a coefficient of determination $\left(R^{2}\right)$. The statistical parameters were calculated by least-square regression and LOD and LOQ were considered as $3 \times \mathrm{S} / \mathrm{N}$ ratio and $10 \times \mathrm{S} / \mathrm{N}$ ratio, respectively. The precision and the recoveries of the method were evaluated by application of the whole procedure to six samples (experimental replicates) spiked at final concentration of $10 \mu \mathrm{g} / \mathrm{kg}$. The precision was expressed as \%RSD of peak areas. Recoveries were calculated as (signal of a spiked sample/signal of a spiked extract) $\times 100$. The fortified samples were extracted, cleaned-up and analyzed by HPLC-FLD as described previously.

\section{Results and discussion}

\section{Method validation data}

All calibration curves showed a good linearity within the range studied since the determination coefficients $\left(R^{2}\right)$ were above 0.99 in all the cases (Table 1). The LODs and LOQs ranged between 0.10 and $0.15 \mu \mathrm{g} / \mathrm{kg}$ and from 0.26 to $0.50 \mu \mathrm{g} / \mathrm{kg}$, respectively. LOQs result satisfactory with respect to acceptance criteria regulated by the European Union. The results of precision study are expressed as \%RSD. In all cases, RSD $<7 \%$ 
Table 1. Linearity data, detection, quantification limits and recoveries for OTA by HPLC-FLD method.

\begin{tabular}{lccc}
\hline Sample & Wheat grain & Fine semolina & Flour \\
\hline Concentration range $(\mu \mathrm{g} / \mathrm{kg})$ & $1-50$ & $1-50$ & $1-50$ \\
Calibration curve & $y=34193 x+20065$ & $y=33557 x+10182$ & $y=34994 x+12225$ \\
$R^{2}$ & 0.9991 & 0.9950 & 0.9972 \\
LOD $(\mu \mathrm{g} / \mathrm{kg})$ & 0.10 & 0.15 & 0.15 \\
LOQ $(\mu \mathrm{g} / \mathrm{kg})$ & 0.50 & 0.26 & 0.40 \\
Precision RSD (\%) & 5.8 & 4.4 & 6.7 \\
Mean recovery (\%) and RSD 7 (\%) & $96.2(5.7)$ & $94.5(6.9)$ & $95.6(6.7)$ \\
\hline
\end{tabular}

Recoveries of OTA for samples spiked at $10 \mu \mathrm{g} / \mathrm{kg}(n=6$, injected in duplicate).

Table 2. OTA contamination wheat samples collected from Algeria.

\begin{tabular}{lccccc}
\hline Region & Type of wheat & $\begin{array}{c}\text { Number of } \\
\text { analyzed samples }\end{array}$ & $\begin{array}{c}\text { Number of positive } \\
\text { samples }(\%)\end{array}$ & $\begin{array}{c}\text { Range of contamination } \\
(\mu \mathrm{g} / \mathrm{kg})\end{array}$ & $\begin{array}{c}\text { Mean of contamination } \\
(\mu \mathrm{g} / \mathrm{kg})\end{array}$ \\
\hline Sétif & DW & 5 & $2(40)$ & $1.36 ; 2.90$ & 2.13 \\
& CW & 2 & $2(100)$ & $1.73 ; 7.48$ & 4.60 \\
Mitidja & DW & 10 & $7(70)$ & $0.78-11.45$ & 3.50 \\
& CW & 7 & $2(28.6)$ & 5.877 .4 & 1.60 \\
Médéa & DW & 6 & $5(83.3)$ & $0.21-7.37$ & 7.09 \\
Tiaret & DW & 6 & $3(100)$ & $5.02-14.74$ & 8.73 \\
& CW & 3 & $27(690)$ & $0.21-27.31$ & 7.09 \\
Total & & 39 & & & \\
\hline
\end{tabular}

were obtained and were in good agreement with the Commission Regulation No. 401/2006 (European Commission, 2006). The recovery values obtained ranged between $94.5 \%$ and 96.2 , are satisfactory and fulfilled the requirements of the Commission Regulation No. 401/2006.

\section{OTA contamination in wheat grain}

Twenty-seven of 39 tested samples were contaminated with OTA at quantities ranging from 0.21 to $27.31 \mu \mathrm{g} /$ $\mathrm{kg}$ (Table 2). Our results revealed that both DW and CW were contaminated by OTA at rate of 74 and $58.33 \%$, respectively. A study conducted on the occurrence of OTA showed that cereal products from the Mediterranean countries are often contaminated with OTA (Zinedine et al. 2006; Riba et al. 2008; Zaied et al. 2009; Jedidi et al. 2016). This is likely due to the climatic conditions favorable to the growth of some fungal species such as Aspergillus (Mantle 2002). The obtained incidence of contamination were above than obtained by Zaied et al. (2009) and Zinedine et al. (2006), who reported a percentage of $38 \%$ of contamination in wheat commercialized in Tunisia and Morocco, respectively. Riba et al. (2008) showed that OTA was detected in $40 \%$ of analyzed Algerian wheat samples, with quantities ranging from 0.21 to $41.55 \mu \mathrm{g} / \mathrm{kg}$. Jedidi et al. (2016) reported that one of the 65 samples of freshly harvested Tunisian wheat was contaminated by OTA. From Ethiopia, Ayalew et al. (2006) reported the presence of OTA in $24.3 \%$ of 321 tested samples, with a mean concentration of
$54.1 \mu \mathrm{g} / \mathrm{kg}$ and a maximum of $2106 \mu \mathrm{g} / \mathrm{kg}$. A higher percentage $(76 \%)$ was obtained in Croatia by Puntaric et al. (2001). Also, OTA was detected in $12.2 \%$ of stored wheat samples in USA (Kuruc et al. 2015). From India, wheat samples were contaminated with detectable quantities of OTA ranging from 1.36 to $21.17 \mu \mathrm{g} /$ $\mathrm{kg}$ including 13 (26\%) samples exceeding the level of $5 \mu \mathrm{g} / \mathrm{kg}$ (Kumar et al. 2012). In our case, and among the positive samples, 13 samples (48.14\%) exceeded the maximum limit of $5 \mu \mathrm{g} / \mathrm{kg}$ in raw cereal grains applied by the European Union (European Commission 2006). The highest levels of OTA in DW $(27.31 \mu \mathrm{g} / \mathrm{kg})$ and CW $(14.74 \mu \mathrm{g} / \mathrm{kg})$ were detected in sample collected from Médéa and Tiaret regions, respectively. The incidence of contamination by OTA was also high in these regions (Tiaret: 100\% and Médéa: $83.3 \%$ ). However, the measured concentration of OTA in DW in Sétif ranges from 1.36 to $2.9 \mu \mathrm{g} / \mathrm{kg}$. In warmer and tropical parts of the world, Aspergillus species seem to be OTA producers. In addition, improper storage conditions can also lead to higher cereals contamination by mycotoxins (Petzinger and Weindenbach 2002). The occurrence of OTA in cereal grains depends on the conditions of the grain at harvest, how carefully the grain is dried and on the storage conditions (Eskola 2002).

\section{OTA contamination in wheat milling fractions}

Among the 42 analyzed wheat-derived samples, OTA was detected in 39 (92.85\%) samples at levels ranging from 0.25 to $34.75 \mu \mathrm{g} / \mathrm{kg}$ in DW products (Table 3 ) and 
Table 3. OTA contamination DW-derived products collected from M'sila Semolina Manufactures.

\begin{tabular}{lcccc}
\hline $\begin{array}{l}\text { Stage of } \\
\text { transformation }\end{array}$ & $\begin{array}{c}\text { Number of } \\
\text { analyzed samples }\end{array}$ & $\begin{array}{c}\text { Number of } \\
\text { positive samples }\end{array}$ & $\begin{array}{c}\text { Range of } \\
\text { contamination }(\mu \mathrm{g} / \mathrm{kg})\end{array}$ & $\begin{array}{c}\text { Mean } \\
\text { contamination }(\mu \mathrm{g} / \mathrm{kg})\end{array}$ \\
\hline Unclean DW & 2 & 1 & 16.24 & 16.24 \\
Cleaned DW & 3 & 3 & $0.40-9.01$ & 4.38 \\
Broken DW & 5 & 3 & $1.41-34.75$ & 7.23 \\
Coarse semolina & 2 & 1 & 4.19 & 4.19 \\
Fine semolina & 2 & 2 & $6.56 ; 9.84$ & 8.2 \\
Extra fine semolina & 2 & 2 & $0.25 ; 4.59$ & 2.42 \\
Durum flour & 3 & 3 & $1.16-6.75$ & 4.07 \\
Bran & 7 & 4 & $0.31-24.28$ & 7.16 \\
Middlings & 3 & 3 & $1.31-14.35$ & 8.65 \\
Total & 29 & 22 & $0.16-34.75$ & 6.95 \\
\hline
\end{tabular}

Table 4. OTA contamination in CW-derived products from M'sila Flour Manufactures.

\begin{tabular}{lcccc}
\hline Stage of transformation & $\begin{array}{c}\text { Number of } \\
\text { analyzed samples }\end{array}$ & $\begin{array}{c}\text { Number of } \\
\text { positive samples }\end{array}$ & $\begin{array}{c}\text { Range of } \\
\text { contamination }(\mu \mathrm{g} / \mathrm{kg})\end{array}$ & $\begin{array}{c}\text { Mean } \\
\text { contamination }(\mu \mathrm{g} / \mathrm{kg})\end{array}$ \\
\hline Unclean CW & 1 & 1 & 7.3 & 7.3 \\
Cleaned CW & 1 & 1 & 6.03 & 6.03 \\
Broken CW & 3 & 3 & $0.36-3.11$ & 2.91 \\
Flour & 3 & 3 & $3.51-15.51$ & 9.49 \\
Bran & 3 & 3 & $2.84-18.18$ & 11.32 \\
Middlings & 2 & 2 & $2.15 ; 5.03$ & 3.59 \\
Total & 13 & 13 & $0.36-18.18$ & 6.77 \\
\hline
\end{tabular}

0.36 to $18.18 \mu \mathrm{g} / \mathrm{kg}$ in $\mathrm{CW}$ products (Table 4). The results of OTA analysis showed that 17 samples (43.58\%) exceeded the European Union threshold of $3 \mu \mathrm{g} / \mathrm{kg}$ for wheat-derived products. In semolina manufacture, the level of OTA in unclean and clean DW was 16.24 and $4.38 \mu \mathrm{g} / \mathrm{kg}$, respectively. It is known that cleaning may reduce mycotoxin concentrations in commoditie but this difference in OTA level may be due to heterogeneity of OTA distribution. Cleaning may not completely remove all of the contamination. Scudamore (2005) showed that only 2-3\% reduction of OTA in barley was achieved by cleaning. Moreover, the initial conditions of the grain, or commodity, and their extent of contamination will have an effect on cleaning efficiency. At the breaking step during DW milling, the concentration of OTA was comprised between 1.41 and $34.75 \mu \mathrm{g} / \mathrm{kg}$ with a mean of $7.23 \mu \mathrm{g} / \mathrm{kg}$. In Extra fine semolina and fine semolina, the mean levels of OTA were 2.42 and $8.2 \mu \mathrm{g} / \mathrm{kg}$, respectively. In durum flour, bran and wheat middlings (fractions mainly intended for animal feeds), the average levels of OTA were $4.07,7.16$ and $8.65 \mu \mathrm{g} / \mathrm{kg}$, respectively. Our results showed that OTA was not eliminated after milling processes and it was just redistributed among milling fractions. This is in agree with published data reported by Pinotti et al. (2016).

The results of OTA contamination in CW products showed the presence of OTA in both unclean $(7.3 \mu \mathrm{g} /$ $\mathrm{kg})$ and in cleaned CW $(6.03 \mu \mathrm{g} / \mathrm{kg})$. For the broken $\mathrm{CW}$ the concentration of OTA ranged between 0.36 and $3.11 \mu \mathrm{g} / \mathrm{kg}$. We note that bran contains high concentration of OTA ranging from 2.84 to $18.18 \mu \mathrm{g} / \mathrm{kg}$ with an average of $11.32 \mu \mathrm{g} / \mathrm{kg}$. In flour, concentration of OTA ranges between 3.51 and $15.51 \mu \mathrm{g} / \mathrm{kg}$ with an average of $9.49 \mu \mathrm{g} / \mathrm{kg}$. Furthermore, many researchers reported that milling processes were effective in reducing mycotoxin in wheat flours by removing contaminated outer layers (bran and shorts). According to Bullerman and Bianchini (2007), during milling process, mycotoxins may be redistributed and concentrated in certain mill fractions, but there is no step or operation that destroys these toxins. Some authors reported that mycotoxins tend to be concentrated in bran fractions (Abbas et al. 1985; Katta et al. 1997; Park 2002; Scudamore et al. 2003; Brera et al. 2004). Levels of OTA are slightly lower in fractions intended for human consumption (semolina and flour) and higher in fractions mainly intended for animal feeds (Cheli et al. 2013). Some parts of mycotoxins are found in broken kernels, by-products, and dust (Hazel and Patel 2004; Kushiro 2008). Many studies reported similar trends in mycotoxins distribution in the various milled-wheat fractions. The retention levels of mycotoxins in semolina and flour were shown to depend on the variety of wheat, the degree of the diffusion of molds, and the move of mycotoxins to the inner parts of the grains (Cheli et al. 2013). El Khoury and Atoui (2010) reported that $50 \%$ of the human daily intake of OTA worldwide was due to the consumption of cereals and their derived products. 


\section{Conclusions}

Because OTA is moderately heat stable and will support most physical food processing, it is important to keep the levels of this mycotoxin to a minimum in cereals that may be used to produce cereal-based products, such as bread and biscuits (Duarte et al. 2010). This study showed that wheat grains and derived products were highly contaminated by OTA ( 69.23 and $92.85 \%$, respectively), where $50 \%$ of positive samples exceeded the EU maximum limit for OTA. This is likely due to the climate conditions (high temperature and humidity), and inappropriate storage conditions and the absence of the Good Manufacturing Practices (GMP) during processing which promote the development of storage fungi like Aspergillus species. In addition, we found that the level of OTA contamination in wheat harvests of 2012 and 2013 seasons is higher than what was reported by Riba et al. (2008) for wheat samples collected from Sétif region in preceding years. The Algeria farmers may not be aware of the OTA problem in wheat due to the lack of a national strategy (norms) to survey and control the quality of seeds from field to final product. Thus, our results may help to establish maximum limits for OTA in foodstuffs commercialized in Algeria, especially in wheat and derived products, and to respect the good agricultural practices like storage conditions in order to minimize OTA contamination and prevent the threat to human health.

\section{Disclosure statement}

No potential conflict of interest was reported by the authors.

\section{ORCID}

Amar Riba (D) http://orcid.org/0000-0002-3445-5367

\section{References}

Abbas, H.K., et al., 1985. Effect of cleaning, milling, and baking on deoxynivalenol in wheat. Applied environmental microbiology, 50, 482-486.

Araguas, C., et al., 2005. Study on ochratoxin A in cerealderivated products from Spain. Food chemistry, 92, 459-464.

Ayalew, A., et al., 2006. Natural occurrence of mycotoxins in staple cereals from Ethiopia. Mycopathologia, 162, 57-63.

Bennett, J.W. and Klich, M., 2003. Mycotoxins. Clinical microbiology reviews, 16, 497-516.

Binder, E.M., et al., 2007. Worldwide occurrence of mycotoxins in commodities, feeds and feed ingredients. Animal feed science technology, 137, 265-282.
Brera, C., et al., 2004. Effect of industrial processing on the distribution of fumonisin B1 in dry milling corn fractions. Journal of food protection, 67, 1261-1266.

Bullerman, L.B. and Bianchini, A., 2007. Stability of mycotoxins during food processing. International journal of food microbiology, 119, 140-146.

Castegnaro, M., et al., 2006. Balkan endemic nephropathy: role of ochratoxin A through biomarkers. Molecular nutrition and food research, 50, 519-529.

Cheli, F., et al., 2013. Effect of milling procedures on mycotoxin distribution in wheat fractions: a review. Food science and technology, 54, 307-314.

Czerwiecki, L., Czajkowska, D., and Witkowska-Gwiazdiwska, A., 2002a. On ochratoxin A and fungal flora in Polish cereals from conventional and ecological farms. Part 1. The occurrence of ochratoxin A and fungi in cereals in 1997. Food additives and contaminants, 19, 470-477.

Czerwiecki, L., Czajkowska, D., and Witkowska-Gwiazdiwska, A., 2002b. On ochratoxin A and fungal flora in Polish cereals from conventional and ecological farms. Part 2. occurrence of ochratoxin A and fungi in cereals in 1998. Food additives and contaminants, 19, 1051-1057.

Duarte, S.C., Pena, A., and Lino, C.M., 2010. A review on ochratoxin A occurrence and effects of processing of cereal and cereal derived food products. Food microbiology, 27, 187-198.

El Khoury, A. and Atoui, A., 2010. Ochratoxin A: general overview and actual molecular status. Toxins, 2, 461-493.

Eskola, M., 2002. Study on trichothecenes zearalenone and ochratoxin $A$ in Finnish cereals: occurrence and analytical techniques. Doctoral dissertation. National Veterinary and Food Research Institute (EELA) and University of Helsinki.

European Commission. 2006. Commission Regulation No 1881/2006 of 19 December 2006 setting maximum levels for certain contaminants in foodstuffs. Official journal of the European union, 364, 5-24.

Food and Agriculture Organization of the United Nations (FAO). 2016. Food security snapshot: Global information and early warning system on food and agriculture (GIEWS) [Internet]. Italy: FAO. Available from: http://www.fao.org/ giews/countrybrief/country.jsp?code $=D Z A$

Hajjaji, A., et al., 2006. Occurrence of mycotoxins (ochratoxin $A$, deoxynivalenol) and toxigenic fungi in Moroccan wheat grains: impact of ecological factors on the growth and ochratoxin A production. Molecular nutrition and food research, 50, 494-499.

Hazel, C.M. and Patel, S., 2004. Influence of processing on trichothecene levels. Toxicology letters, 153, 51-59.

International Agency for Research on Cancer (IARC). 1999. IARC monographs on the overall evaluations of carcinogenicity to humans. Lyon, 1, 1-36.

Jedidi, I., et al., 2016. Aflatoxins and ochratoxin A and their Aspergillus causal species in Tunisian cereals. Food additives and contaminants part $B$ surveill, 10, 51-58.

Kabak, B., 2009. The fate of mycotoxins during thermal food processing. Journal of the science of food and agriculture, 89, 549-554.

Katta, S.K., et al., 1997. Distribution of Fusarium molds and fumonisins in dry-milled corn fractions. Cereal chemistry, 74, 858-863. 
Kuiper-Goodman, T., 1996. Risk assessment of ochratoxin A: an update. Food additives and contaminants, 13, 53-57.

Kumar, R., et al., 2012. Detection of ochratoxin A in wheat samples in different regions of India. Food control, 26, 63-67.

Kuruc, J.A., Schwarz, P., and Wolf-Hall, C., 2015. Ochratoxin A in stored U.S. barley and wheat. Journal of food protection, 78, 597-601.

Kushiro, M., 2008. Effects of milling and cooking processes on the deoxynivalenol content in wheat. International journal of molecular sciences, 9, 2127-2145.

Lombaert, G.A., et al., 2003. Mycotoxins in infant cereal foods from the canadian retail market. Food additives and contaminants, 20, 494-504.

Malir, F., et al., 2016. Ochratoxin A: 50 years of research review. Journal toxins, 8, 191.

Mantle, P.G., 2002. Risk assessment and the importance of ochratoxins. International biodeterioration and biodegradation, 50, 143-146.

Murphy, P.A., et al., 2006. Food mycotoxins, an update. Journal of food science, 71, 51-65.

Osborne, B.G., et al., 1996. The effects of milling and processing on wheat contaminated with ochratoxin A. Food additives and contaminants, 13, 141-153.

Park, D.L., 2002. Effect of processing on aflatoxin. Advances in experimental medicine and biology, 504, 173-179.

Petzinger, E., and Weindenbach, A., 2002. Mycotoxins in the food chain: the role of ochratoxins. Livestock production science, 76, 245-255.

Pfohl-Leszkowicz, A., et al., 2002. Balkan endemic nephropathy and the associated urinary tract tumours, review on etiological causes, potential role of mycotoxins. Food additives and contaminants, 19, 282-302.

Pinotti, L., et al., 2016. Mycotoxin contamination in the EU feed supply chain: a focus on cereal byproduct. Toxins, $8,45$.
Puntaric, D., et al., 2001. Ochratoxin A in corn and wheat: geographical association with endemic nephropathy. Croatian medical journal, 42, 175-180.

Riba, A., et al., 2008. Mycoflora and ochratoxin A producing strains of Aspergillus in Algerian wheat. International journal of food microbiology, 122, 85-92.

Rodrigues, I., and Naehrer, K., 2012. A three-year survey on the worldwide occurrence of mycotoxins in feedstuffs and feed. Toxins, 4, 663-675.

Scudamore, K.A., 2005. Prevention of ochratoxins $A$ in commodities and likely effects of processing fractionation and animal feeds. Food additives and contaminants, 1, 17-25.

Scudamore, K.A., Banks, J., and MacDonald, S.J., 2003. Fate of ochratoxin $A$ in the processing of whole wheat grains during milling and bread production. Food additives and contaminants, 20, 1153-1163.

Tabuc, C., et al., 2009. Molds and mycotoxin content of cereals in southeastern Romania. Journal of food protection, 72, 662-665.

Vidal, A., et al., 2013. Determination of aflatoxins, deoxynivalenol, ochratoxin $A$ and zearalenone in wheat and oat based bran supplements sold in the Spanish market. Food chemistry and toxicology, 53, 133-138.

Wolff, J., 2000. Ochratoxin A in cereals and cereal products. Arch. Lebensmittelhyg, 51, 85-88.

Zaied, C., et al., 2009. Natural occurrence of ochratoxin A in Tunisian cereals. Food control, 20, 218-222.

Zinedine, A., et al., 2009. Pressurized liquid extraction coupled to liquid chromatography for the analysis of ochratoxin $A$ in breakfast and infants cereals from Morocco. Food control, 4, 009.

Zinedine, A., et al., 2006. Natural occurrence of mycotoxins in cereals and spices commercialized in Morocco. Food control, 17, 868-874. 